\title{
Matrimonios y conflictos: abandono, divorcio y nulidad eclesiástica en la Andalucía moderna (Arzobispado de Sevilla, siglo XVIII) ${ }^{1}$
}

\author{
Alonso Manuel Macías Domínguez \\ Universidad de Huelva \\ alonsomanuel.macias@dhis2.uhu.es \\ María Luisa CANDAU CHACóN \\ Universidad de Huelva \\ candau@dhis2.uhu.es
}

Recepción: 24 de diciembre de 2015 / Revisión: 31 de marzo de 2016

Aceptación: 11de abril de 2015 / Publicación: Diciembre de 2016

\section{RESUMEN}

Regulado nuevamente el matrimonio en el Concilio de Trento y ratificada su indisolubilidad, es evidente que la realidad conyugal no siempre marcharía por los caminos propuestos. Abordamos aquí el matrimonio como espacio de conflictos en donde las desavenencias y los problemas de convivencia (incluida la violencia o la infidelidad) propiciaron la solicitud de separación o divorcio (temporal o perpetuo), de demandas de nulidad eclesiástica y, en dirección contraria, de petición de "vida maridable". Analizamos tales pleitos y causas en un espacio -Arzobispado de Sevilla- a lo largo del Siglo XVIII, sin olvidar ni el contexto histórico, ni las posibilidades brindadas por el derecho canónico.

Palabras clave: Pleitos matrimoniales, divorcio, nulidad, abandono conyugal. Concilio de Trento, Sevilla, España, siglo XVIII.

\section{Marriage and Conflict: Conjugal Desertion, Divorce and Ecclesiastical Annulment in Modern Andalusia (Archbishopric of Seville, $18^{\text {th }}$ Century)}

\begin{abstract}
Despite new marriage regulations of the Council of Trent and the ratification of the indissolubility of the institution, conjugal realities clearly didn't always follow proposed paths. In this article we approach matrimony as a locus of conflicts in which disagreements and problems of conviviality (including violence or infidelity) propitiated requests for separation or divorce (temporary or perpetual), ecclesiastical annulment and, contrarily as well, petitions for marital life. We analyze these lawsuits and trials within
\end{abstract}

1 Este trabajo se inserta en el marco de dos proyectos de financiación del Ministerio de Economía y Competitividad, MINECO, I+D Las mujeres y las emociones en Europa y América. Siglos XVII-XIX, HAR201237394; La vida emocional de las mujeres: experiencias del mundo, formas de la sensibilidad. Europa y América, 1600-1900. HAR2015/63804-P. 
the context of the Archbishopric of Seville throughout the $18^{\text {th }}$ century, without disregarding the historical context nor the possibilities afforded by Canon Law.

Keywords: Marriage Lawsuits, Divorce, Annulment, Conjugal Desertion, Council of Trent, Seville, Spain $18^{\text {th }}$ century.

Sumario: 1. Introducción: los objetivos, las fuentes, el espacio y el tiempo. 2. El número: problemas de cuantificación. 3. Ellos y ellas. Perfiles y protagonismos. 4. La violencia de género, protagonista en las demandas de separación. 5. Ellos y ellas. Sexualidad, infidelidades, abandonos, adulterio: problemas comunes, percepciones diferentes. 6 . El divorcio en los márgenes de la sociedad: las idas y venidas de Josef González y Francisca Santana. 7. Conclusiones. 8. Referencias bibliográficas.

\section{INTRODUCCIÓN: LOS OBJETIVOS, LAS FUENTES, EL ESPACIO Y EL TIEMPO}

Cualquier acercamiento a la realidad conflictiva del matrimonio en la España del Antiguo Régimen pasa imperativamente por el vaciado de las fuentes judiciales sitas en los archivos diocesanos. En efecto, siendo el matrimonio sacramento nuevamente regulado en el Concilio de Trento ${ }^{2}$ y declarado, en cuanto tal, competencia exclusiva de la Iglesia Secular, y más detenidamente del obispo, las probabilidades de separación, temporal o perpetua, como de disolución del vínculo caían de lleno en la autoridad eclesiástica. De este modo, si bien las demandas de cumplimiento de promesa de matrimonio podían solventarse ante tribunales civiles y eclesiásticos, por ser causa de fuero mixto, las relativas a su interrupción o anulación no contaban con competencia civil. De ahí que la realidad documental, manifiesta en sus pleitos, se contenga en exclusividad en los fondos episcopales y diocesanos.

Pretendemos mostrar el matrimonio como espacio de conflictos, partiendo de un presupuesto obvio: nos situamos allí donde los actos de conciliación fracasaron y se impuso el recurso al litigio. Donde naturalmente no se encuentran todos los problemas conyugales, entre otras cosas porque ni todas las parejas contaban con la capacidad de iniciar los trámites de un pleito de estas características, ni todos los problemas conyugales buscaban soluciones de pleitos: desgraciadamente la ruptura de la convivencia buscaba a veces un final trágico y los problemas finalizaban violentamente, eliminándose así las posibilidades y las necesidades de abogados y procesos. Los escenarios y las tramas del ejercicio de la fuerza, sin embargo, se trasladarán aquí como fondo argumental, de forma que la traducción del término "conflicto" no pocas veces tomaba forma de enfrentamiento físico.

Nos situamos en el marco espacial del Arzobispado Hispalense, territorios expandidos por las actuales provincias de Sevilla, Huelva, parte norte de Cádiz, y pequeñas poblaciones del sur de Badajoz y el oeste de Málaga. Un espacio que, a mediados del XVIII, según el vecindario de Ensenada (1759), contaba con un buen número de

\footnotetext{
2 El decreto Tametsi fue aprobado de forma definitiva por los padres conciliares con 126 votos a favor, 47 en contra y siete abstenciones, el día 10 de noviembre de 1563. Po-CHIA Hsia, 2010, p. 41.
} 
poblaciones superiores a los mil vecinos, entre las que -amén de una Sevilla no tan floreciente por el traslado de la Casa de Contratación a Cádiz- destacaban ciudades y agro-villas como Jerez de la Frontera, Écija, El Puerto de Santa María, Carmona, Osuna o Sanlúcar de Barrameda. El entorno urbano era relevante, los comportamientos notarán su influencia. A fines del siglo XVIII (Censo de Floridablanca), habitaban en el reino de Sevilla 754.293 almas. Sevilla aglomeraba una población urbana superior al $41 \%{ }^{3}$.

Desde el punto de vista eclesiástico, y a diferencia de otras archidiócesis de la Corona de Castilla, en Andalucía occidental triunfa la demarcación vicarial. Así, en tanto que el arciprestazgo primaba en otros espacios, en la provincia eclesiástica de Sevilla y en su arzobispado, la vicaría -conjunto de parroquias- marcaba las directrices de la vida oficial de la Iglesia. A su frente el vicario foráneo dirigirá los asuntos de su circunscripción y -sobre todo en los espacios más distantes de la capital- marcará el camino de los procesos. Con ellos los curas de las parroquias cobran protagonismo en un espacio y en unos tiempos en los que el socio-centrismo (definido en su día por Henry Kamen) demostraba, en su expresión, "la fuerza inmensa de la Iglesia". La vida transcurría en los límites de la vecindad, la collación, el barrio o, como mucho, la localidad; y los lazos afectivos se dirigían, religiosa y sensiblemente hablando, hacia la parroquia, la imagen y la hermandad. En estos ambientes, y dependiendo del grado de urbanización, el control vecinal o eclesiástico de las costumbres pasaba, aquí en el Sur, por un conocimiento extendido de las vidas de los otros; en las conocidas como casas-patio, lo privado era público y los conflictos, y entre ellos los conyugales, se conocían. De ahí que no faltasen testigos para deponer en cualquiera de los pleitos citados. A favor o en contra.

El mundo que recorremos a lo largo del XVIII aborda los problemas y conflictos domésticos en situaciones tan diversas (y tan parecidas en su origen) como los malos tratos, la infidelidad, el desencuentro de caracteres o incluso el cambio de rumbo en las directrices familiares; todo lo cual podía derivar -en no pocos casos extraoficialmente- en la interrupción de la convivencia. Convivencia que -bien lo sabían las mujeres de entonces- se proyecta aquí en sus extremos: el sentimiento de propiedad de la esposa seguía estando vigente en la sociedad moderna y patriarcal, y se encontraba en buena parte de estos procesos.

\section{EL NÚMERO: PROBLEMAS DE CUANTIFICACIÓN}

El estudio de los expedientes de ruptura conyugal rastreados a lo largo del siglo XVIII, (referentes a abandono de vida maridable, divorcio y nulidad vincular) proceden de dos fuentes. Primero: las resultas y resúmenes contenidos en los Libros de indices correspondientes a los años 1707-1762; incluyen los pleitos matrimoniales

\footnotetext{
3 EIRAS, 2009, pp. 39-40.
} 
que pertenecieron al oficio II del arzobispado ${ }^{4}$; segundo: los pleitos matrimoniales actualmente conservados.

Los citados índices recogen un total de 301 pleitos entre 1707 y 1762; considerando que se trata de los pertenecientes a un solo oficio, habríamos de, como máximo, duplicarlos; de ellos 121 (40.19\%) serían de divorcio, 44 (14.61\%) de nulidad y $136(45.18 \%)$ de abandono de vida maridable. Pero no poseemos más información a partir de entonces (1762). Los procesos reales conservados distan de tales cifras, pues para toda la centuria A.M. Macías en su tesis doctoral inédita encontró sólo 169 expedientes: $88(52.07 \%)$ de divorcio, $19(11.24 \%)$ de nulidad y $62(36.68 \%)$ por "abandono de vida maridable", en su inmensa mayoría concentrados en la segunda mitad del siglo 5 .

Las muestras reflejan, en ambos casos, una primacía evidente de las causas por abandono y divorcio sobre las de nulidad eclesiástica. En los últimos cuarenta años se observa un crecimiento relativo de los divorcios por encima de las nulidades y un descenso de las causas por abandono de vida maridable; las conclusiones a vuela pluma apuntan una cierta institucionalización y oficialización de la ruptura, convertida en separación o divorcio (en vez del simple abandono) -lo que se producirá entre los grupos acomodados y urbanos según se verá- y unas menores posibilidades de disolución del vínculo por la vía de la solicitud de la nulidad eclesiástica. Considerando entonces la validez de los datos contenidos en tales libros de índices, aun concentrados en un número menor de años, la archidiócesis hispalense se situaría entre la práctica barcelonesa y la vitalidad conflictiva gaditana, entre otros análisis de espacios peninsulares ${ }^{6}$.

Y sin embargo creemos que no todo en la Historia puede ser cuantificable. Primero, porque prima la minoría, efecto, bien de la dramatización de las circunstancias, bien de las posibilidades, y ambas características suelen marchar conjuntas. Segundo

4 Índice de los autos que pasaron ante el oficio II del arzobispado entre 1707 y 1762 . Archivo General del Arzobispado de Sevilla (en adelante AGAS), Sección Justicia, Serie Pleitos, Signatura 10871. El gobierno de los tribunales del arzobispado hispalense contaba con dos oficios que se distribuían el trabajo en función del índice alfabético de los pueblos. Para su funcionamiento véase PINEDA, 2015.

5 Tiempos para los que no hemos hallado registros ni índices.

6 Para la diócesis de Pamplona se han contabilizado 1.556 procesos matrimoniales en los siglos XVI y XVII, de los cuales 171 están vinculados con la ruptura de la vida conyugal. 59 de ellos pertenecen a la tipología de nulidad. CAMPO, 1998, pp. 89 y 160; en el caso del tribunal de Zamora, los números se reducen: 36 demandas de anulación, 63 de divorcio y 16 de vida maridable para el siglo XVII. LorENZO, 1999, pp. 141 y 156; en Coria sólo se han rastreado 5 procesos de ruptura. PéREZ MuÑoz, 1992, pp. 52-54; para Barcelona, diócesis con sede en una urbe relevante, se ha rastreado en cambio la notable suma de 220 peticiones de separación entre 1565 y 1798. GiL, 1992, pp. 120-121. Y lo mismo puede señalarse para la diócesis de Cádiz en el siglo XVIII, cuya dinámica población llega a proponer 380 peticiones de nulidad y de divorcio. MoRGADO, 1994-1995, p. 126. En el ámbito colonial, Bernard Lavallé ha contabilizado las sobresalientes cifras de 928 demandas de divorcio y 605 de nulidad en el Arzobispado de Lima desde 1651 a 1700, que refieren la existencia de serias dificultades en ese territorio para implantar el modelo matrimonial confeccionado por la Iglesia. Lavallé, 1999, p. 23. Para el Arzobispado de Córdoba (Argentina) las cifras son también notables pero quedan muy lejos de las alcanzadas en el distrito peruano: entre 1688 y 1850 se incoaron 214 procesos de ruptura legal: 146 de separación de vidas, y 68 de nulidad vincular. GHIRARDI - IRIGOYEN, 2009, p. 254. En el obispado de Concepción (Chile, mediados s. XVIII-fines s. XIX) los números son muy reducidos: entre los expedientes eclesiásticos, 18 divorcios y 7 nulidades (más 3 matrimonios clandestinos y 6 bigamias, contabilizados aparte), y entre los civiles, 21 divorcios y 4 nulidades (más 4 matrimonios clandestinos y 16 bigamias). GonZÁLEZ, 2011, pp. 95-102. 
porque ignoramos los abandonos espontáneos y las decisiones conyugales de ruptura - unilaterales o compartidas-, historias de vidas desconocidas que escapaban del control eclesiástico, y que reproducían en lugares ajenos nuevas parejas y nuevas familias, o que las combinaban. He aquí un ejemplo: entre 1758 y 1763, Francisco Pereda, natural de Ayamonte, mantuvo doble vida (y casa doble) entre la ciudad onubense y la capital gaditana. Al calor de los negocios de Indias, había marchado temporalmente a Cádiz, en donde antiguos conocidos portugueses que andaban de paso le descubrieron con mujer, supuestamente legítima, pero diferente a la propia que residía -y le conocían- en su ciudad de origen. Ambas de igual nombre -Josepha- se repartieron la agitada vida del ayamontino, finalmente descubierto ${ }^{7}$. Este comportamiento prácticamente bígamo, oficialmente adúltero, por no existir una segunda ceremonia, refleja la existencia de situaciones que no serán tratadas judicialmente ni como causas de abandono de "vida maridable" (la legítima contaba con esposo aun "a tiempo parcial") ni de divorcio, ni de nulidad ni, por supuesto, según hemos citado, de bigamia. Pero para la vida real, la vida que cuenta, todas las circunstancias y todos los agravantes coincidían en esta historia. Así pues, ¿no deberíamos contemplar en su conjunto y combinadamente tales expedientes -a la postre de adulterio y de amancebamiento con agravantes- con los mencionados pleitos matrimoniales de separación o disolución del vínculo? ¿No hubiera denunciado la mujer legítima a su marido por abandono, de no llevar éste una doble vida? Las cifras, al final moderadas, de estos pleitos deben ser estudiadas a la luz de los que no se produjeron, adquiriendo una mayor importancia, no los números sino sus causas. Porque las omisiones y la continuidad de vidas supuestamente "regulares" también tienen su porqué.

Reproducimos a continuación tablas conteniendo los datos procedentes de ambos estudios, separadamente por las razones citadas: en tanto sabemos con una mayor precisión los pleitos iniciados entre 1707 y 1762 -bien que ante un solo oficio-, no ocurre igual para los últimos cuarenta años del siglo. Por otra parte no se encuentran los correspondientes a los años de 1700-1707 y 1714, efecto de las influencias de la Guerra de Sucesión; asimismo en las anotaciones contenidas en los últimos años no computan (según aparece en los propios libros de índices) "84 ramos de pleitos diversos" (entre ellos los de abandono de vida maridable) lo que incrementaría moderadamente su porcentaje en el total de autos. Las apuntaciones indican "autos relajados", lo que indicaría autos desistidos y evidencia la existencia de arreglos infra-judiciales. Es evidente que el incremento de la población marcaba las pautas, como los factores bélicos y, en los casos de abandono, las llamadas "acciones de oficio", obviamente inexistentes en los pleitos matrimoniales de divorcio y nulidad.

7 CANDAU, 2009. 
Tabla 1. Procesos de ruptura matrimonial en el Arzobispado de Sevilla según los Libros de Índices (1707-1762). Oficio II.

\begin{tabular}{|c|c|c|c|c|c|c|c|}
\hline \multicolumn{8}{|c|}{$\begin{array}{l}\text { PLEITOS DE DIVORCIO, NULIDAD Y CAUSAS POR ABANDONO } \\
\text { DE VIDA MARIDABLE (Libros de índices) } \\
\text { (Arzobispado de Sevilla, Oficio II, 1707-1762) }\end{array}$} \\
\hline & $\begin{array}{l}1707- \\
1713(*)\end{array}$ & $\begin{array}{l}1715- \\
1725\end{array}$ & $\begin{array}{l}1726- \\
1736\end{array}$ & $\begin{array}{l}1736- \\
1746\end{array}$ & \begin{tabular}{|l|}
$1746-$ \\
1756
\end{tabular} & $\begin{array}{l}1756- \\
1762(* *)\end{array}$ & Total \\
\hline Divorcio & 14 & 21 & 14 & 32 & 25 & 15 & $\begin{array}{l}121 \\
(40.2 \%)\end{array}$ \\
\hline Nulidad & 12 & 11 & 5 & 5 & 4 & 7 & $44(14.6 \%)$ \\
\hline $\begin{array}{l}\text { Petición } \\
\text { de V.M. }\end{array}$ & & 1 & 11 & 30 & 65 & 29 & $\begin{array}{l}136 \\
(45.2 \%) \\
\end{array}$ \\
\hline Total & 26 & 33 & 30 & 67 & 94 & 51 & 301 \\
\hline \multicolumn{8}{|c|}{$\begin{array}{l}(*) \text { No constan años anteriores, ni el de } 1714 \text {, posiblemente efecto de la Guerra de Sucesión } \\
(* *) \text { : En el índice de los años } 1756-1757 \text { y } 1758 \text {, consta "siguen (en fuera de Sevilla, } 84 \text { ramos de } \\
\text { autos relajados de Palabras de casamiento, jactancia y vida maridable a petición del fiscal, de } \\
\text { diferentes años, propiciados y no no seguidos") }\end{array}$} \\
\hline
\end{tabular}

Gráfico 1. Evolución temporal de los procesos de ruptura matrimonial en el arzobispado de Sevilla según los Libros de Índices (1707-1762). Oficio II.

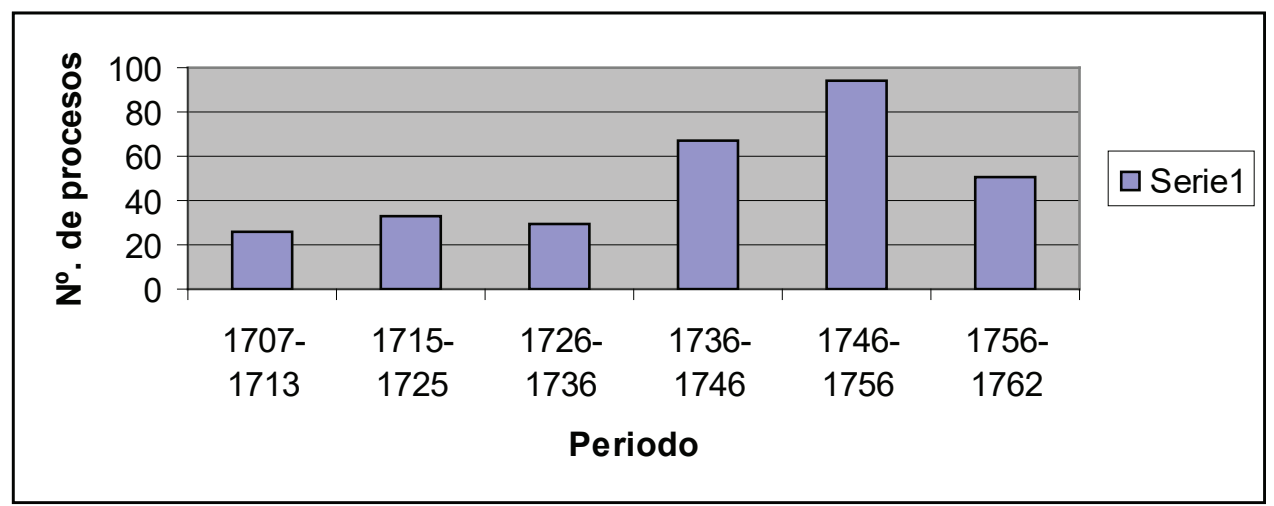

Fuente: Elaboración propia.

Los expedientes conservados -según citamos, distribuidos casi totalmente en la segunda mitad- quedan reflejados, globalmente, en las siguientes tabla y gráfica. 
Tabla 2. Procesos de ruptura matrimonial en el Arzobispado de Sevilla (documentación conservada) (1701-1800).

\begin{tabular}{|c|c|c|c|c|c|c|c|c|c|c|c|}
\hline \multicolumn{12}{|c|}{$\begin{array}{l}\text { PLEITOS CONSERVADOS DE DIVOR } \\
\text { DE VIDA MARIDABLE (Expedientes) } \\
\text { (Arzobispado de Sevilla, 1700-1800) }\end{array}$} \\
\hline & $\begin{array}{c}1701- \\
1710\end{array}$ & $\begin{array}{c}1711- \\
1720\end{array}$ & $\begin{array}{l}1721- \\
1730\end{array}$ & $\begin{array}{l}1731- \\
1740\end{array}$ & $\begin{array}{l}1741- \\
1750\end{array}$ & $\begin{array}{l}1751- \\
1760\end{array}$ & $\begin{array}{l}1761- \\
1770\end{array}$ & $\begin{array}{l}1771- \\
1780\end{array}$ & $\begin{array}{l}1781- \\
1790\end{array}$ & $\begin{array}{l}1791- \\
1800\end{array}$ & Total \\
\hline $\begin{array}{l}\mathrm{D} \text { i - } \\
\text { vorcio }\end{array}$ & 1 & - & - & - & - & 25 & 21 & 15 & 13 & 13 & $\begin{array}{l}88 \\
(52 \%)\end{array}$ \\
\hline $\begin{array}{l}\text { Nuli- } \\
\text { dad }\end{array}$ & - & - & 1 & 1 & - & 2 & 9 & 2 & 4 & - & $\begin{array}{l}19 \\
(11.3 \%)\end{array}$ \\
\hline $\begin{array}{l}\text { Peti- } \\
\text { c ión } \\
\text { V.M. }\end{array}$ & - & - & - & 1 & - & 33 & 18 & 6 & 3 & 1 & $\begin{array}{l}62 \\
(36.7 \%)\end{array}$ \\
\hline Total & 1 & - & 1 & 2 & - & 60 & 48 & 23 & 20 & 14 & 169 \\
\hline
\end{tabular}

Gráfico 2. Evolución temporal de los procesos conservados de ruptura matrimonial en el arzobispado de Sevilla (1701-1800).

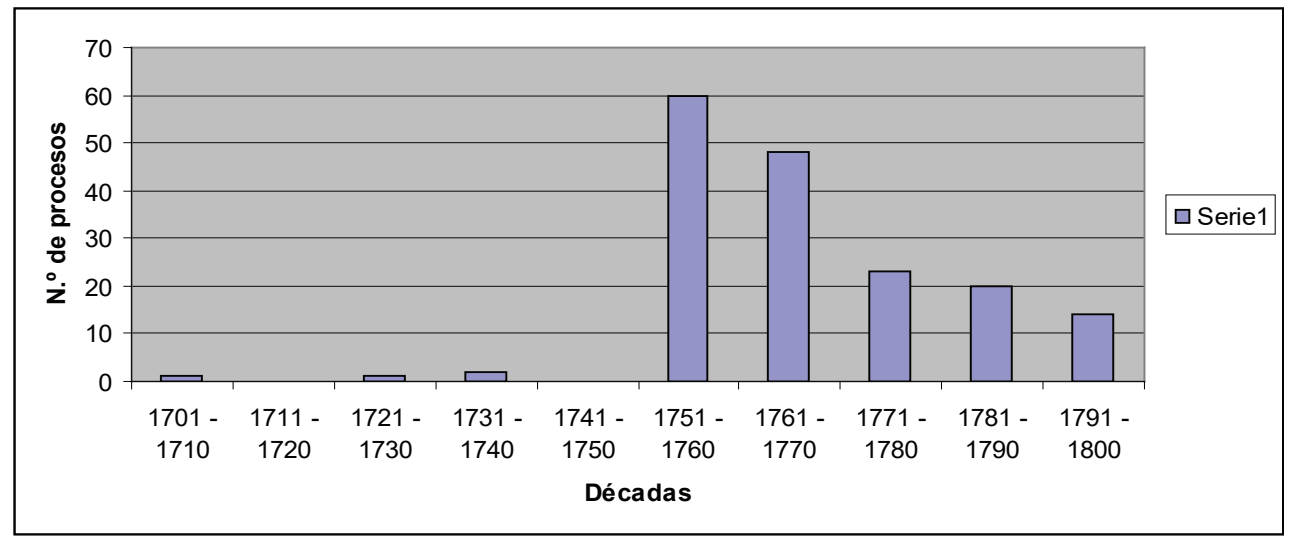

Fuente: Elaboración propia.

Como puede comprobarse, la distribución temporal de los procesos conservados se inicia prácticamente en la década de los cincuenta: entre 1751 y 1760, unos 60 expedientes de litigio matrimonial. A partir de entonces y hasta fines de siglo, el número de pleitos tiende a descender. De los 48 autos que encontramos para los años 17611770, pasamos a los 23 de 1771-1780 y a los 20 de 1781-1790. Para los últimos diez años del siglo sólo contamos con 14 procesos, un 76,67\% menos que los rastreados entre 1751 y 1760 .

A fines de siglo, la aceptación de las formas legales de ruptura de la convivencia, entiéndase por la vía del divorcio, se ratifica. Aclararemos sin embargo la conexión y 
continuidad entre algunos de los procesos estudiados de diferentes ramos; en efecto hallaremos expedientes de divorcio que se iniciaron tras una primera demanda por abandono de vida maridable, en su día iniciada por un esposo abandonado -o por el fiscal general del arzobispado-, y seguida por el inicio de un pleito de ruptura legalizada ${ }^{8}$. Abandono del hogar que precedía a la demanda de separación, presentada comúnmente por la esposa ante el temor de una reacción violenta del marido.

Hemos de señalar, además, el sesgo social anejo a este tipo de fuentes. En gran medida, los procesos legales de ruptura (divorcio) son impulsados por miembros de los grupos medios y altos lo cual se manifiesta claramente en función de las profesiones de sus protagonistas, según veremos. Por tanto, una progresiva desaparición de los procesos por ausencia de vida maridable nos aleja de la visión de conjunto de la sociedad, porque la representación de los sectores populares disminuirá al ritmo de la segunda mitad del siglo.

\section{ELLOS Y ELLAS. PERFILES Y PROTAGONISMOS}

Como en la mayoría de los trabajos citados, las mujeres protagonizaron las demandas de divorcio. Los Libros de Índices mencionados presentan una aplastante mayoría de las mujeres: entre 1707 y 1751 , el $97 \%$ de las demandas lo fueron por las esposas. Aún más: las veinte solicitudes anotadas contenidas en la década 1725-1735 les correspondieron en su totalidad ${ }^{9}$. Los expedientes conservados demuestran asimismo tales supremacías, en menor proporción: más de un $70 \%$. Las razones vienen a confirmar un panorama conocido: las llamadas mal casadas andaluzas iniciarán pleito ante -casi siempre- necesidades de supervivencia frente a maridos maltratadores y violentos (73.5\% de las demandas femeninas, en la segunda mitad del XVIII). Pues si bien el Derecho canónico abogaba por la unidad de los casados, defendía también, obviamente, el derecho a la vida. Otros autores han mantenido la valentía de las mujeres en estas decisiones de separación ${ }^{10}$, o el deseo de liberación conformando verdaderas actitudes de rebeldía ${ }^{11}$ en sociedades cuyos valores seguían siendo la sumisión al marido y la obediencia consecuente; asimismo la existencia de separaciones espontáneas en tiempos determinados (conflictos bélicos, por ejemplo). Aquí, sin embargo,

\footnotetext{
8 Las cifras relativas a los procesos por abandono de vida maridable sólo contabilizan los autos que no derivan posteriormente en una demanda de nulidad o de divorcio, en cuyo caso se incluyen en alguna de estas dos categorías, según corresponda. Hemos considerado esta clasificación como la más acertada y más acorde con el sentido real de los procesos: entre las demandas de anulación o de separación de cuerpos, aunque vayan precedidas de una queja por abandono de hogar, ésta no deja de ser una especie de preludio de la acción judicial contundente, que se inicia con la solicitud de la separación/anulación reconocidas. En este estudio hemos integrado todos estos casos en las tipologías definitivas en las que concluyen, esto es, en las de separación o anulación, toda vez que en este caso el abandono del hogar tiene connotaciones diferentes a las propias de los pleitos de vida maridable: entre los planes de los infractores parece estar presente ya la presentación de la demanda judicial.

9 Pese a estar anotadas 121 demandas de divorcio, sólo consta mención al demandante en 65; de ellas 63 fueron iniciadas por las mujeres.

10 CAMPO, 1998, p. 121

11 Costa, 2009, p. 97.
} 
la situación era más simple: no tanto una actitud de valentía cuanto de desesperación. Hallarse en riesgo la vida.

Para el varón, las circunstancias, contradictoriamente, dificultaban sus demandas. Al ser reconocida su autoridad, cualquier planteamiento de separación comportaba el reconocimiento de sus defectos: no haber sabido ejercer su dominio, bien ante las actuaciones de una esposa insumisa, bien ante -lo que era peor- el conocimiento público de unas relaciones adúlteras del cónyuge, lo que ni la estima social ni el derecho canónico permitían mantener. En el primer caso, porque las representaciones del honor consideraban aún su supremacía física y racional, de forma que el incumplimiento de sus funciones le desacreditaba. Las estampas burlescas dibujaban mujeres montando asnos, símbolos de dominio, entre otras cosas. En el segundo caso porque el conocimiento de las relaciones adúlteras -mantenidas supuestamente por la esposa- y la ausencia de delación hacían recaer en el marido el título de consentidor: una de las actitudes delictivas más perseguidas por parte de la justicia eclesiástica. En todos los casos analizados de la Sevilla Moderna tales reos serían condenados a los presidios africanos ${ }^{12}$. La separación legal constituía, entonces, la única vía para recuperar honor y lavar afrenta, reparando así virilidad y hombría, conceptos vinculados en la Modernidad con la capacidad de control sobre la mujer y el ejercicio de la autoridad ${ }^{13}$.

Las reticencias de los maridos a solicitar demanda de divorcio nacían también de sus consecuencias económicas. Primero porque, en casi todos los casos, los pleitos implicaban la financiación por parte del marido de los costes de la manutención de la mujer, en tanto durase el proceso, y en algunos de ellos, incluso, el pago de las litisexpensas o gastos del litigio ${ }^{14}$. Segundo, porque la consecución del divorcio (perpetuo) acarreaba la división del patrimonio conyugal, de forma que el marido habría de devolver los bienes dotales entregados por la mujer o su familia al tiempo de la celebración del enlace.

No es de extrañar, entonces, que los abandonos del hogar fuesen protagonizados por el varón (llamémosle abandonos espontáneos) en tanto que las separaciones legales fuesen cuestiones de mujeres: en muy pocas ocasiones tales demandas iniciadas por la esposa vienen precedidas por la marcha del esposo ${ }^{15}$. La presencia de las casadas como demandantes del regreso de sus maridos resulta nimia, fuese por circunstancias promovidas por el "alivio" de la nueva situación o por la imposibilidad de obtener éxito en tales asuntos.

Tales actitudes y sus protagonistas parecen comunes. Salvo determinadas excepciones en las que el peso de las solicitudes masculinas supera al de las femeninas ${ }^{16}$, la realidad localizada para el caso sevillano del siglo XVIII queda reproducida en la mayor parte de los tribunales diocesanos hispanos, tanto en la metrópoli como en las

12 CANDAU, 2002.

13 LaVallé, 1999, p. 30; Torremocha, 2015.

14 CAmpo, 1998, p. 118.

15 De los 40 pleitos de divorcio conservados precedidos por demanda de vida maridable, sólo tres fueron iniciados por las mujeres; 20 lo fueron por hombres y el resto, 17, fueron por vía de oficio. Ignoramos el papel que en éstas últimas tuviera la mujer, de forma indirecta.

16 Hernández González, 1998, p. 39. No se recogen datos cuantitativos al respecto. 
colonias. En España, los trabajos efectuados en Extremadura ${ }^{17}$, Navarra ${ }^{18}$, Zamo$\mathrm{ra}^{19}$, Barcelona ${ }^{20} \mathrm{o} \mathrm{Cádiz}^{21}$, plasman sin vacilaciones este desequilibrio cuantitativo a favor de las mujeres demandantes. Y para el mundo indiano, los datos relativos a México demuestran la existencia de paralelismos evidentes con la Península ${ }^{22}$.

Se trata de un fenómeno persistente, detectado ya en los dos primeros siglos de la Edad Moderna, y sostenido más allá de los límites temporales de la etapa; así, en el tránsito del Antiguo al Nuevo Régimen, las cifras se mantienen: casi el 70\% de los procesos de divorcio presentados ante la curia barcelonesa entre 1775 y 1833 fue promovido por las esposas ${ }^{23}$. Asimismo en Europa ${ }^{24}$. Un panorama mantenido, incluso tras la llegada del liberalismo al mundo occidental, evidencia de la persistencia del problema más allá de las restricciones impuestas por los sistemas modernos al colectivo femenino; restricciones que se mantendrán, en buena medida, después ${ }^{25}$.

Es evidente que el estatus social perfila los protagonismos. Pues si bien las demandas integran a todos los sectores sociales, no todos lo hicieron con la misma inten-

17 Testón, 1985, p. 163. Aunque se expone cómo "son, ante todo, las mujeres las que imploran justicia y piden que su matrimonio pueda ser disuelto" a través del divorcio legal, no se explicitan datos concretos al respecto.

18 CAMPo, 1998, p. 120. Las solicitudes de divorcio femeninas suponen el $82,4 \%$ del total, frente al $16,8 \%$ de las masculinas y al $0,80 \%$ de las conjuntas.

19 LorEnzo, 1999, p. 156. El $94 \%$ de las solicitudes de separación conyugal fue incoado por mujeres en la diócesis zamorana durante el siglo XVII.

20 GIL, 2008, p. 207. De los 191 procesos de divorcio presentados a la curia de Barcelona entre 1565 y 1654, 177 fueron incoados por mujeres y el resto (14) por hombres.

21 Morgado, 1994-1995, p. 126. Los esposos iniciaron 48 procesos de separación matrimonial, frente a los 241 presentados por las esposas.

22 Sobre México, Dávila, 2005, p. 191. De las 300 demandas de divorcio presentadas ante el tribunal diocesano mexicano, 193 fueron propuestas por mujeres.

23 Costa, 2009, p. 97.

24 Fauve-Chamoux, 2002, p. 369. Entre 1710 y 1736, el 70\% de los solicitantes de separación en la diócesis de Cambrai fueron mujeres, y otro $5 \%$ de las demandas fueron presentadas de forma conjunta. La investigadora asegura además que la presencia femenina creció a lo largo del siglo XVIII, vinculando esta situación con una posible mayor emancipación de la mujer. En Italia los resultados son más complejos: al efectuar una lectura de conjunto sobre los diversos territorios de la península itálica, Giovanni Ciappelli refleja un decrecimiento paulatino del protagonismo femenino entre los demandantes en las causas matrimoniales a lo largo de la Modernidad. En el siglo XV fueron mayoritarios los varones $(50,5 \%)$ en Venecia. Durante el siglo XVI la mujer toma la iniciativa de forma decidida (55\% en Verona y Feltre excluyendo los abiertos "de oficio", $60 \%$ en Nápoles), pero comienzan a atisbarse síntomas de estancamiento en el XVII (59\% en Trento, $41 \%$ en Feltre y $52 \%$ en Nápoles). En el siglo XVIII las demandas femeninas sólo representan el 39\% del total en Trento y el $41,5 \%$ en Feltre. Estos datos deben, con todo, ser tomados con cautela: no se refieren en exclusiva a los procesos de divorcio sino al conjunto de procesos matrimoniales incoados (declaración de validez de matrimonios, esponsales, divorcios, nulidades, y otros), pudiendo esta explicación conjunta alterar la correcta lectura de los datos, Ciappelli, 2006, p. 93. Por ello, se hace forzoso recurrir a los datos parcelados por tipologías. En Venecia, por ejemplo, entre 1420 y 1500 existe una preponderancia masculina en el inicio de procesos de separación (66 hombres frente a 39 mujeres), mientras en Trento se verifica una situación contraria (31 mujeres y 23 hombres) para el periodo comprendido entre 1632 y 1803 . En Nápoles la acción de las mujeres se encuentra detrás de la mayor parte de las instancias de divorcio, previas y posteriores a 1563: entre 1496 y 1563 ellas promueven 59 procesos, frente a los 30 propuestos por ellos; entre 1563 y 1699, serán 167 las mujeres y 121 los hombres que soliciten el fin de la vida maridable. SEIDEL, 2005, pP. 157-158.

25 Cliche, 1995, pp. 9-18. Entre 1795 y 1879 el distrito judicial de Montreal juzgó un total de 253 procesos de divorcio, de los cuales 13 fueron impulsados por varones y 240 por mujeres. La causa alegada con mayor frecuencia, como viene siendo habitual, fue la violencia conyugal. 
sidad. La mayor parte pertenece a los grupos medios y acomodados; así, aunque los pleitos no recojan datos específicos, la inclusión de anotaciones profesionales aclara en algo el panorama social. Siendo mayoría las profesiones liberales y la condición nobiliaria (caballeros de órdenes militares, por ejemplo) ${ }^{26}$, la ausencia de las grandes casas otorga lustre a los grupos medios y medios-altos. Así abundan las referencias a familias con criados o negocios propios, como las quejas sobre bienes gastados; y la habitual preocupación de las mujeres por sus bienes dotales acentúa la idea de un grupo de pleiteantes adinerados que supera con mucho al de los grupos humildes ${ }^{27}$. Encontramos también militares de graduación ${ }^{28}$.

Por el contrario, los grupos populares escasean. Algunas criadas, algún trabajador del campo o soldado raso, un cortador de pescado y otros sujetos de parecida extracción. Ello pese a la alegación de ser pobre, de proporciones no desdeñables del conjunto. Una condición que apunta el lógico interés por obtener exención del pago de derechos en los procesos, pero que no siempre corresponde a la realidad (en términos relativos) de entonces. Así, constatamos que algunos de los autos de despacho por pobre fueron concedidos a personas con una situación que no era, patrimonialmente, tal, si bien el propio inicio del pleito cambiaría en no pocas ocasiones las circunstancias vitales de la mujer. Tales situaciones se identifican, entonces, con las esposas pertenecientes a grupos medios que se declaran sin recursos suficientes para el ejercicio de su defensa ante la justicia, alegando el manejo de los bienes por sus maridos. Al juzgarse exclusivamente el patrimonio personal en las solicitudes de pobreza y no valorarse el perteneciente a familiares -padres, esposo o hermanos-, algunas mujeres lograban sus propósitos pese a no ser, en puridad, personas pobres. El caso de doña Josefa María del Carmen García puede servirnos de ejemplo: en octubre de 1779 solicitará del tribunal el reconocimiento de su imposibilidad material para afrontar los gastos del pleito de divorcio de su esposo, don Miguel Noboa. De inmediato, el tribunal ordenará poner en práctica las diligencias oportunas para averiguar la situación real de la suplicante, solicitando certificación del clero parroquial y testimonios ratificatorios. La respuesta del cura, acorde con los intereses de la demandante, asegurará tratarse de una mujer sin recursos ni bienes propios, "pobre de solemnidad", para mayor carga, encamada y encinta ${ }^{29}$, una declaración que no cuadraba con los testimonios de

\footnotetext{
26 Demanda de divorcio de doña María Charril y Vidarte contra su esposo don Antonio Reynoso. El Puerto de Santa María, 1704. AGAS, Sección Justicia, Serie Divorcios, leg. 14.190. Don Antonio Reynoso es caba1lero de la Orden de Santiago.

27 La presencia de mujeres pudientes ante la autoridad, pretendiendo protección para sus bienes frente a un marido derrochador, es una realidad persistente en la Sevilla durante toda la Edad Moderna. Para fines del XVI e inicios del XVII, véase SÁNCHEZ CID, 2011, p. 127.

28 Don Juan Francisco Roco, alférez reformado de caballería y agregado al estado mayor de esta ciudad, marido y conjunta persona de doña Juana de Vega, residente en la de Sanlúcar de Barrameda, con la referida su mujer, sobre que se venga a esta ciudad a hacer vida maridable con el referido su marido en una casa y compañía, como Dios Nuestro Señor manda y tiene obligación. AGAS, Sección Justicia. Serie Palabra de Casamiento, leg. 13.877. Don Juan Francisco Roco, de quien pretende separarse su mujer doña Juana de Vega, es alférez reformado de caballería.

29 El infrascripto cura más antiguo en esta iglesia de Señor San Vicente de esta ciudad, certifico que doña Josefa García, mujer legítima de Miguel de Noboa es mi parroquiana, pobre de solemnidad, enferma y según me informan está embarazada de cinco meses, y que el médico la está asistiendo, y para que conste a pedimento de la parte, doy la presente en Sevilla y octubre veinte y cuatro de mil setecientos setenta y nueve
} 
testigos que la recordaban bien alimentada y vestida pero que, a la postre, le valdría la declaración de pobreza.

El predominio de los grupos medios en las demandas de separación y divorcio no se manifiesta en otros espacios: ni siquiera en las cercanas Extremadura o Cádiz ${ }^{30}$, mucho menos en la Lima Colonial ${ }^{31}$ donde predominaban los grupos populares. En la archidiócesis de Sevilla, tampoco, hallamos, como era de esperar, presencia de grupos marginados: ningún esclavo, liberto, negro o mestizo se vería inmerso en un proceso de separación matrimonial a lo largo del siglo, consecuencia necesaria de la configuración racial de la población peninsular ${ }^{32}$. Tan sólo se ha encontrado un proceso en el que el demandado pertenece al pueblo gitano.

El perfil descrito para el caso de los divorcios se repite parcialmente entre los demandantes de nulidad matrimonial y de incumplimiento de vida maridable. De nuevo serán ellas, las mujeres, las protagonistas; ellas quienes soliciten -en un porcentaje superior a los varones- la disolución del vínculo o la vuelta del cónyuge, según el caso y los intereses. Las razones, también similares a las expuestas, se incardinan nuevamente en el delicado papel jugado por la mujer en el ámbito matrimonial.

Entre los procesos por incumplimiento de vida maridable, el juicio popular $-\mathrm{y}$ legal- sobre la convivencia de los casados, pese a los posibles daños por una relación tormentosa, limitaría el recurso al abandono del hogar. Los motivos económicos pesaron especialmente entre las mujeres, recurriendo a la partida ilegal tan sólo las más osadas, las más amenazadas o, principalmente, las que contaban con mayores posibilidades de supervivencia en solitario. No olvidemos, además, el perjuicio a la honra de la esposa huida, que habría de inventar vida y personalidad en lugares relativamente lejanos. Los varones, por el contrario, contaban con mayores posibilidades prácticas de partir del hogar en solitario, no sólo por su capacidad de movilidad, sino también por la mayor laxitud de los códigos morales aplicables a su género y, de forma especial, por la capacidad de sustentarse con su trabajo sin necesidad de depender de su cónyuge. Por estas razones los varones partieron con una mayor asiduidad.

Este panorama varía en el conjunto de procesos formados por una demanda por incumplimiento de vida maridable más una solicitud de divorcio posterior. Siendo las mujeres más activas que ellos en la petición de separación, también lo son en la ruptura unilateral de la convivencia (vida maridable). En realidad estamos ante un grupo de historias excepcional, en el que el abandono del hogar sólo es empleado como recurso previo a la presentación de la demanda de divorcio, sustrayéndose a la supervisión del esposo, en donde la consecuente denuncia por parte del marido pretendería

años. Don Ignacio Domínguez, cura. Doña Josefa María del Carmen García, mujer legítima de don Miguel de Noboa, vecina de esta ciudad, con el referido su marido, sobre separación y divorcio del matrimonio entre los susodichos contraído. Certificación de pobreza. AGAS, Sección Justicia, Serie Palabra de Casamiento, leg. 13.874, folio $1 \mathrm{r}$.

30 Testón, 1985; MoRgado, 1994-1995.

31 LAVALLÉ, 1999, pp. 27-31.

32 En Indias, donde la segregación social por causa de raza es tan potente como en la Península, pero la presencia de grupos étnicos distintos mucho más sobresaliente, los individuos pertenecientes a los grupos no españoles tuvieron un papel destacado en la presentación de solicitudes de divorcio. En el arzobispado de Lima, representaron alrededor del $25 \%$ del total de demandantes en la segunda mitad del siglo XVII. LAVALLÉ, 1999, p. 27. 
ocultar la responsabilidad propia, señalando la contraria. De las 40 demandas incluidas aquí, 20 fueron propuestas por ellos, 17 por vía de oficio, y sólo 3 por las mujeres.

La nulidad matrimonial conforma un grupo de características especiales por la propia naturaleza de esta figura jurídica, bajo la cual pueden acogerse individuos deseosos de romper definitivamente el lazo creado, junto a otros que se ven abocados al final de su matrimonio por causas físicas o legales (impotencia, consanguinidad). Constatamos la presencia de ambos sexos entre los querellantes, aunque en cifras que distan de ser equilibradas: 5 hombres frente a 14 mujeres y 1 por vía de oficio. Ellos y ellas aprovecharon la subjetividad del consentimiento viciado para intentar una desunión detestada por otras causas, principalmente la fuerza ejercida por la justicia entre los varones o el desacuerdo familiar entre las mujeres. Un escenario de interpretaciones personales que no cabe en otras tipologías, denunciadas, principalmente, por ellas: la impotencia y la bigamia. Dolencia física e infracción legal grave que atañen principalmente a los varones, bien por configuración biológica, bien por la mayor libertad de movimientos que les es concedida.

La representación de la escala social es casi tan parcial como en el caso del divorcio, aunque la intensidad se relaje aquí. El valor del matrimonio en la Modernidad movió a personas de todos los escalafones sociales a solicitar el cumplimiento de la vida maridable. La vida conjunta posee un valor en sí misma del que carece la separación, una opción que queda relegada a minorías con posibles. Y ante la necesidad perentoria de asegurar la supervivencia y el buen nombre, las dificultades propias del proceso judicial o incluso de las distancias geográficas pueden ser obviadas.

Entre los solicitantes de la anulación vincular detectamos una mayor presencia de los sectores pudientes, aunque no exclusiva. Algunos casos de posible riqueza familiar, conectados a las demandas por falta de consentimiento o por ingreso en religión, se mezclan con otros de clara procedencia popular. Como es obvio, la impotencia no afecta más a unos grupos que a otros, y su traslado al tribunal tampoco parece responder a un comportamiento de clase concreto. Sí puede establecerse una relación más fiable entre bigamia/sectores no acomodados. La bigamia moderna se vincula al movimiento geográfico de los infractores, empujados por las dificultades materiales en los lugares de origen, siendo en consecuencia una tipología que afecta poco a los sectores pudientes, menos necesitados de cambiar de residencia y con menos opciones de ocultar la existencia antigua.

\section{LA VIOLENCIA DE GÉNERO, PROTAGONISTA EN LAS DEMANDAS DE SEPARACIÓN}

La mayoría de las demandas presentadas por las mujeres alegaba malos tratos como causales de la petición de separación o divorcio. Los expedientes conservados desde 1750 muestran su primacía. Las sevicias imperaban. 
Tabla 3. El maltrato denunciado por las mujeres en las demandas de divorcio conservadas.

\begin{tabular}{|c|c|c|c|c|c|c|c|}
\hline Fecha & $\begin{array}{c}N^{o} \text { de } \\
\text { demandas }\end{array}$ & $\begin{array}{c}\text { Maltra- } \\
\text { to fisico }\end{array}$ & $\%$ & Insultos & $\%$ & $\begin{array}{c}\text { Violencia } \\
\text { con otros } \\
\text { familiares }\end{array}$ & $\%$ \\
\hline $1751-1760$ & 22 & 14 & 63,64 & 14 & 63,64 & 2 & 9,09 \\
\hline $1761-1770$ & 15 & 15 & 100 & 13 & 86,67 & 3 & 20 \\
\hline $1771-1780$ & 9 & 5 & 55,56 & 4 & 44,44 & 0 & 0 \\
\hline $1781-1790$ & 12 & 7 & 58,33 & 5 & 41,67 & 0 & 0 \\
\hline $1791-1800$ & 10 & 8 & 80 & 9 & 90 & 0 & 0 \\
\hline TOTAL & 68 & 50 & 73.52 & 46 & 67.64 & 6 & 8,8 \\
\hline
\end{tabular}

Fuente: Elaboración propia.

Más del 70\% de las mismas (73.5\%) refería escenas de violencia y humillación como reflejo de una vida diaria que permitía -en muy diferentes y moderadas formaslas tareas de corrección del esposo a la esposa ${ }^{33}$. Considerando que el riesgo de la vida promovía en los tribunales eclesiásticos la actuación en su defensa, el concepto de maltrato hacia la mujer (hoy violencia de género) poseía unas connotaciones bastante más radicales y extremas. Es cierto que tales argumentos pudieron ser utilizados en beneficio de las mujeres en sus pretensiones, sabiendo de la normativa y de los causales más exitosos a la hora de conseguir sentencias positivas, pero la normalización de ciertos discursos y los testimonios permiten entrever la realidad de una violencia doméstica extendida. Dos tercios (67.6\%) incluyeron referencias a insultos e injurias (malos tratos de palabra) comúnmente acompañando a las escenas violentas: una realidad que parece general en diversos espacios peninsulares: en el Sur como en el Norte ${ }^{34}$ y que concentra en las esferas domésticas el incremento de su ejercicio, al margen del proceso de civilización vivido por el mundo occidental en los Tiempos Modernos $^{35}$. Antes bien, la legislación existente, la producción eclesiástica y mora-

33 Las cifras referentes a mujeres demandantes (aquí 68) responden a aquellas que intervinieron bien a comienzos, bien a mitad de un pleito matrimonial; son las denominadas "demandas cruzadas", razón por la cual alteran la contenida en la tabla anterior, donde las demandas conservadas iniciadas por las esposas serían 64. La diferencia alude a quienes se incorporaron en expedientes iniciados por sus cónyuges.

34 De hecho, algunos trabajos centrados en la evolución de la violencia marital demuestran una evolución creciente de las demandas de este tipo delictivo durante el Setecientos: para Cantabria y entre 1650-1830, Tomás Antonio Mantecón ha demostrado una tendencia alcista general a partir de 1650, con épocas de especial virulencia vinculadas a la existencia de coyunturas económicas desfavorables (1709 y 1770-1790) y otras de suavización de los conflictos. MANTECón, 2002.

35 Muchembled, 2010. El autor otorga el elocuente título de La violencia domesticada al capítulo dedicado al amplio periodo que transcurre entre 1650 y 1960, al que caracteriza por el importante descenso de las tasas de asesinato, que quedan en cifras bajas ya en el siglo XVIII. Aunque el descenso es particularmente acentuado en esta tipología delictiva, es perceptible una tendencia decreciente para el resto de ataques violentos: respecto a la "violencia física sin consecuencias fatales", concluye Muchembled que "el empleo de la 
lizante, y la percepción social generalizada aceptaban el recurso al correctivo como medio para el mantenimiento del orden jerárquico familiar. En palabras de María José de la Pascua era "una violencia permeada por las representaciones culturales de la masculinidad y la feminidad" ${ }^{36}$. Y una violencia, además, que los discursos buscaban, si no justificar -no podía serlo en los casos extremos- sí sufrir, en la medida de lo posible con resignación. Argumentos que las demandas incluían en las defensas realizadas por los abogados. Como muy bien usaría a fines de siglo la propia de doña María de la Merced en el pleito de divorcio contra su marido, Antonio del Villar; llevada de su celo religioso, la esposa había aguantado tal situación, viendo en ella la "cruz" que todo fiel había de soportar, guardando vida y felicidad para "la vida eterna":

La mía, no olvidada del santo temor de Dios y recientemente instruida en las obligaciones del matrimonio, abrazó su cruz, prometiéndose llevarla con paciencia, y conseguir por ello la vida eterna, graduándose con fuerzas para restituir las adversidades que se anunciaba, pero el tiempo la ha dado un desengaño de la imposibilidad de llevar su cruz, por la sevicia del marido, e injurias que continuamente le traía la conciencia inquieta, al paso que en la ocasión próxima de perder la vida ${ }^{37}$.

Tal defensa y discurso correspondían a los de una mujer de posición. Con criados que a veces mediaban (físicamente) entre porrazos e instrumentos de contundencia (sillas entre otras "armas"), su vida "recreada" reflejaba bien el comportamiento exigido: resignación cristiana en puridad. Pero las escenas de violencia eran tan amplias como las situaciones que las propiciaron; tan diferentes y tan parecidas como sus protagonistas y tan populares como sus barrios. En el Arenal de Sevilla, en 1772, la

fuerza para resolver disputas se halla literalmente invalidado, a la vez por el Estado de derecho y por el desarrollo, desde el siglo XVII" (p. 369). Ello, claro está, contemplando la existencia de resistencias al proceso y de disimilitudes espaciales (entre países, campo/ciudad). Sobre la violencia doméstica y conyugal se muestra más cauto, a causa del silencio mantenido en torno a esta realidad durante tantos siglos. Refiere el abandono paulatino de las agresiones familiares sangrientas (al igual que en el espacio público, aquí también "el combate a puño limpio, según unas reglas precisas, sustituye poco a poco el enfrentamiento con navajas" (p. 247). Pero entendido como "el santuario inviolable de la masculinidad por las burguesías triunfantes", aun con la llegada del Liberalismo el hogar sigue estando bajo el dominio del padre de familia. El aumento de las denuncias por violencia contra las mujeres (los uxoricidios crecen un 75\% en Inglaterra y Gales entre 1841 y 1900), con todo, parecen responder no sólo al incremento de los episodios sufridos sino también, y especialmente, a una mayor concienciación hacia la denuncia judicial (pp. 255-256). Un ejemplo de modificación sólo parcial se encuentra en la Cantabria rural del Antiguo Régimen: de acuerdo con Tomás A. Mantecón Movellán, el número de procesos por pendençia aumentó a partir de 1690 en las localidades de Lloredo, Cayón y Reocín hasta finales de la Modernidad, pero el porcentaje de agredidos fallecidos disminuyó respecto a la etapa 1630-1690. MANTECón, 1997, pp. 271-278. En este caso, la violencia se mantiene o acentúa, pero se recortan las consecuencias más graves; transformaciones que el autor vincula con el devenir de cacicazgos y redes clientelares. Para el caso de Cádiz, María José de la Pascua presenta un panorama caracterizado por una baja incidencia de las querellas por homicidios y heridas entre 1596 y 1680 , un fuerte repunte entre 1681 y 1700 , y cifras relativamente menores a partir de entonces. Los números pertenecientes a los años 1777-1792, también contemplados, siguen siendo menores que los de finales del siglo XVII. De LA PaScua, 2012a.

36 De la Pascua, 2012b.

37 Doña María de la Merced Antúnez, vecina de Osuna, mujer legítima de Antonio del Villar, con el referido su marido sobre separación y divorcio del matrimonio entre los susodichos contraído. 1791. Demanda. Francisco Moreno de Luque en nombre de doña María de la Merced y Antúnez. Sevilla, 27-VII-1791. AGAS, Sección Justicia, Serie Divorcios, leg. 14.191, folios 2 r-8 r. 
escena de persecución de un marido hacia su esposa presenta esta trama callejera de un conflicto que se pasaría a ser de conocimiento público:

ha hecho nuevos excesos, castigando a mi parte cruelmente, persiguiéndola hasta la calle, pidiendo y buscando cuchillo con que lograrlo y derribando a mi parte en tierra, le dio nuevos golpes, que hubiera continuado a no estorbarlo la gente que al lance acudió y todo esto sin causa (...). De estos sucesos podrían referirse muchos, pero baste el apuntado y el sucedido en El Arenal, donde con piedras hirió dicho su marido a mi parte porque quiso impedirle tuviese amistad con cierta mujer.

Y continúa:

de manera que a una esclava no podía tratarse así, pues todo esto es acompañado de no alimentar a mi parte, y haberla hecho enfermar por los malos humores que en sus distracciones ha adquirido su marido, y cualesquiera causa de éstas sola es suficiente para el divorcio ${ }^{38}$.

Obviamente los malos tratos no venían solos: como bien expresaba la defensa anterior, la violencia de género podía conectar con causas añadidas: los problemas referentes a la sexualidad y, sobre todo a la infidelidad cuando ésta comportaba abandono, violencia y riesgo de la vida, se encontraban tras las actitudes de sevicias.

\section{ELLOS Y ELLAS. SEXUALIDAD, INFIDELIDADES, ABANDONOS, ADULTERIO: PROBLEMAS COMUNES, PERCEPCIONES DIFERENTES}

Pese a las posibilidades ofrecidas por la legislación, las esposas de esta parte de Andalucía no explotaron bien las situaciones sufridas de infidelidad de sus esposos a la hora de solicitar la separación de cuerpos por la vía de las demandas de divorcio. Para comprender esta situación, se hace imprescindible no sólo conocer la normativa existente, sino también la percepción social vigente acerca del adulterio masculino: el rechazo absoluto reservado a las mujeres infieles se convierte en simple reprobación, indiferencia o incluso comprensión, cuando el culpable es el marido. Las diferencias de género son, en este sentido, radicales, de modo que la situación de engaño que podía tolerar una esposa, sin verse deshonrada por la comunidad, convertía en el caso contrario al marido en el centro de todas las burlas y murmuraciones; el varón engañado se siente más herido y afrentado en su honor que la mujer en idéntica circunstancia. El Antiguo Régimen constituye un "mundo homocéntrico" capaz de perdonar al varón las conductas que considera imperdonables en la mujer ${ }^{39}$.

\footnotetext{
38 José Alcaide, marido de Sebastiana Josefa González, vecinos de esta ciudad, con la referida su mujer, sobre que se junte a hacer vida maridable en una casa y compañía como Dios Nuestro Señor manda y tiene obligación. Y demanda de divorcio puesta por la dicha su mujer. José María Chaves en nombre de Sebastiana González. 16-XI-1772. AGAS, Sección Justicia, Serie Divorcios, leg. 13.800, ff. 20 r-21 v.

39 Hernández Franco - Meriñán, 1997. Referencia en p. 135.
} 
Tabla 4. Motivos alegados por las mujeres en los pleitos de divorcio conservados: la sexualidad y sus transgresiones (1750-1800).

\begin{tabular}{|c|c|c|c|c|c|c|c|c|c|}
\hline Fecha & $\begin{array}{l}\text { Número } \\
\text { de deman- } \\
\text { das }\end{array}$ & $\frac{\sqrt{3}}{\frac{3}{3}}$ & $\%$ & 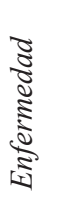 & $\%$ & 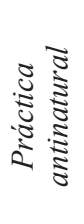 & $\%$ &  & $\%$ \\
\hline $1751-1760$ & 22 & 1 & 4,55 & 3 & 13,64 & 1 & 4,55 & 1 & 4,55 \\
\hline 1761-1770 & 15 & 4 & 26,67 & 3 & 20 & 0 & 0 & 1 & 6,67 \\
\hline $1771-1780$ & 9 & 1 & 11,11 & 2 & 22,22 & 1 & 11,11 & 0 & 0 \\
\hline $1781-1790$ & 12 & 5 & 41,67 & 4 & 33,33 & 0 & 0 & 1 & 8,33 \\
\hline $1791-1800$ & 10 & 2 & 20 & 1 & 10 & 0 & 0 & 1 & 10 \\
\hline TOTAL & 68 & 13 & 19,11 & 13 & 19.11 & 2 & 2,94 & 4 & 5,88 \\
\hline
\end{tabular}

Fuente: Elaboración propia.

Realmente y en gran medida, podemos atribuir a las esposas demandantes esta misma mentalidad: las referencias al engaño de sus maridos suelen ser marginales $\mathrm{y}$, casi sin excepción, acompañando a los verdaderos fundamentos de sus demandas: malos tratamientos, abandono, enfermedad contagiosa... La certeza del engaño no es una causa suficiente para solicitar el fin de la vida maridable por parte de las mujeres: en las historias en las que está presente la infección venérea, resultando evidente la infidelidad, se mencionará el adulterio como causa para el divorcio sólo de forma tangencial, siendo el verdadero deseo de estas narraciones el de convencer al juez del riesgo que se derivaría de la unión sexual. Un ejemplo: la historia planteada en la demanda de Francisca Argana, quien en su solicitud alegará todas las vejaciones realizadas por su marido, Francisco Pro: malos tratos, injurias e insultos, expulsión del hogar, falta de manutención o embriaguez; la infidelidad sólo aparecerá al final de la demanda, tras el empleo de las fórmulas habituales con las que se cierra este tipo de documentos ${ }^{40}$. El adulterio, una de las principales causas reconocidas por los juristas para la ruptura de la convivencia, quedará postergado a una posición secundaria. La realidad es que los tratos del varón seguirían contando con cierta comprensión social; a veces usados por la misma defensa del esposo adúltero. En las cartas de don Torcuato Montellano, a la sazón en tierras de Nueva España, dirigidas a su esposa, en la ciudad de Cádiz, su propia culpa -amancebamiento con una tal Juanita- contaba con

40 El fiscal general de este arzobispado con Francisco Pro y Francisca Argana su mujer, vecinos de la ciudad de Écija, sobre que se junten a hacer vida maridable. Demanda. Felipe Ladrón de Guevara en nombre de Francisca Argana. Sevilla, 16-VI-1758. AGAS, Sección Justicia, Serie Palabra de Casamiento, leg. 13.888, ff. 6 r-7 v. 
el reconocimiento del actor: "si te escriben de que he estado amancebado o viviendo en mala vida no lo he podido remediar" 41 . Los argumentos no paraban en su "mea culpa", que al fin -continuaba- la separación de ambos por negativa de la cónyuge a desplazarse a Indias le había llevado a tal relación ilícita. Como varón (y el tribunal lo era) se le entendía ${ }^{42}$. Ni uno ni otro deseaban la reconciliación. La obligación de Don Torcuato de retomar su vida maridable en la Península, forzado por la justicia de Nueva España, impulsaría a la esposa a su solicitud de divorcio. Estaban bien estando distanciados.

Pero ¿y los esposos? Los datos contenidos en la tabla adjunta muestran, proporcionalmente, pese a su moderación, una mayor importancia concedida al engaño femenino; o un uso porcentualmente superior de tales delitos en el discurso de los hombres. En datos absolutos, sin embargo, creemos que su escasez conecta con unas denuncias o demandas planteadas únicamente en caso de ser conocidas públicamente, bien para evitar deshonor, bien para huir de la tacha (y el castigo) que comportaba el ser acusado de consentidor.

Tabla 5. Motivos alegados por los hombres en los pleitos de divorcio conservados: los problemas sexuales (1750-1800).

\begin{tabular}{|c|c|c|c|c|c|}
\hline Fecha & $N^{\circ}$ de demandas & Adulterio & $\%$ & $\begin{array}{c}\text { Resistencia } \\
\text { a la cohabi- } \\
\text { tación }\end{array}$ & $\%$ \\
\hline $1751-1760$ & 5 & 2 & 40 & 1 & 20 \\
\hline $1761-1770$ & 8 & 4 & 50 & 0 & 0 \\
\hline $1771-1780$ & 7 & 3 & 42,86 & 0 & 0 \\
\hline $1781-1790$ & 1 & 1 & 100 & 0 & 0 \\
\hline $1791-1800$ & 6 & 3 & 50 & 0 & 0 \\
\hline TOTAL & 27 & 13 & 48,15 & 1 & 3,7 \\
\hline
\end{tabular}

Fuente: Elaboración propia.

Frente a estas cifras, las correspondientes a la inobservancia de los deberes de las esposas (desde el punto de vista de sus maridos), manifiesta en percepciones de insumisión, desobediencia o marcha del hogar, constituyeron, proporcionalmente, un

41 Doña Francisca de Paula Ortiz, vecina de esta ciudad, mujer legítima de don Torcuato Montellano, residente en la de Cádiz, con el referido don Torcuato su marido, sobre separación y divorcio del matrimonio entre los susodichos contraído. 1791. AGAS, Sección Justicia, Serie Palabra de Casamiento, leg. 13.825.

42 “... Hija en vista de todo y de que en ti jamás he encontrado (aún para el uso de lo que manda el matrimonio) cariño alguno, el Señor te ampare y a tus desgraciados hijos los libre de todo mal, y ojalá Dios te (ilegible) el corazón de mandármelos, que ellos serían dichosos. Si te escriben de que he estado amancebado, o viviendo en mala vida, no lo he podido remediar, pues de esto y de las demás culpas que cometa, en el tribunal divino te haré las cargas correspondientes, o tú me las harás a mí de las faltas que has tenido de alimentos o decencia, por causa de no haberte socorrido en tiempo, bajo de este supuesto y el de que no me queda ya camino por donde reducirte para el camino de nuestra salvación, adiós hija, y darles en mi nombre con las veras de todo mi corazón y cariños a tus amados hijos". Ibídem. 
recurso mayor. Caracteres bravos y genios insumisos comportaron acusación usada en el $63 \%$ de las demandas presentadas por los maridos. Todo en consonancia con los valores de entonces ${ }^{43}$. Quedaba claro de qué se quejaban los hombres. En contraposición, el abandono conyugal del varón (entiéndase en su faceta de inasistencia material), independientemente del agravante de que tales huidas estuviesen marcadas por otras presencias femeninas, conformaron la queja principal de las mujeres. La necesidad material primaba: el abandono material constaba en 40 de los 69 pleitos iniciados por las mujeres.

\section{EL DIVORCIO EN LOS MÁRGENES DE LA SOCIEDAD: LAS IDAS Y VENIDAS DE JOSEF GONZÁLEZ Y FRANCISCA SANTANA}

La realidad documental conservada de los pleitos de divorcio en esta parte de la Andalucía occidental mostraba un cuadro en donde primaban los grupos medios. Razón de más para recuperar ahora algunas vidas conflictivas de los márgenes en las que, si bien no inicialmente, los enfrentamientos que comenzaron en querellas criminales finalizaron, por alguna de las partes, en demandas de divorcio. Tal era la diferencia en las formas de actuación de los grupos sociales: muy posiblemente la mayoría de las demandas populares tendría por comienzo, no la demanda en sí, sino los conflictos de infidelidad, abandono o sevicias, derivados luego, en casos extremos, en pleitos de separación o divorcio ${ }^{44}$. Así ocurriría en las historias (pues fueron muchas) de la vida conyugal de Josef González y Francisca Santana ${ }^{45}$. Sevilla, collación de El Salvador, fines del XVIII. En 1780, Josef González, cortador de pescado entre otros oficios (que le salían), solicita demanda de separación y divorcio de su esposa, Francisca, con quien había contraído matrimonio cinco años atrás. Los causales alegados centrarán su petición en motivos varios y conocidos: insubordinación de la cónyuge, falta de recato, injurias al honor del marido y abandonos continuados del hogar, un recorrido que los abogados recogerán a la perfección al señalar, negándolos en Francisca, los valores de la buena esposa. Su delito principal (pues como tal se le juzgaba por las dos Justicias), el abandono y la desobediencia: “que según la disposición legal debe estar subordinada en todo a mi parte, como que es su marido". Recogemos a continuación fragmentos esenciales de la demanda por varias razones. Primero, por recorrer, según los intereses del esposo, los puntos básicos en los que sustentar la demanda, segundo, por escenificar la vida de una "mala" esposa y los vejámenes hacia el honor del marido; tercero, por ser, sobre todo, públicos y cuarto, porque a finales del XVIII el avance del poder civil aseguraba la persecución de la justicia real en los casos de abandono del hogar; tanto más si se trataba de la esposa.

\footnotetext{
4317 de los 27 divorcios planteados por los hombres contemplaban este causal. Siete añadían abandono de la esposa. Macías, 2014, pp. 413 y ss.

44 Una hipótesis que pudiera explicar, relativamente, las cifras tan moderadas de las solicitudes encontradas en el Arzobispado sevillano.

45 AGAS, Sección Justicia, Serie Criminales, leg. 1049.
} 
que hace más tiempo de cinco años y medio, contrajo matrimonio el dicho J.G. mi parte, con la enunciada Francisca... en todo lo cual le ha estado asistiendo, según sus fuerzas y haberes, pero, lejos de tener la enunciada la recíproca correspondencia, a que en conciencia por derecho está obligada, lo ha ejecutado en portarse sin subordinación alguna y recato, antes por el contrario con un total abandono... exponiéndole y provocándole con su modo, además de injuriar su honor. Esto se comprueba de que la susodicha, contra la voluntad de mi parte, sale y entra en los bodegones en la calle de los arbolarios, tratándose con las gentes que entran en semejantes casas, con un modo resuelto y sin recato alguno... no siéndole lícito, por derecho, semejante procedimiento, pues según la disposición legal debe estar subordinada en todo a mi parte, como que es su marido... y con poco pudor, la referida Francisca, se va a las tabernas públicas, a presencia de todos, y sin distinción de horas, a beber vino y mistela y demás licores... y, lo que es más, a presencia de mi parte, haciendo alarde de que lo abandona... y se ha salido de las casas donde habita, pernoctando a deshoras y sin venir hasta las que se le antoja, siendo unas veces después de las nueve y media y diez de la noche sin que le haya bastado a esto el que la Justicia Real Ordinaria se lo ha hecho saber haga vida maridable (subrayado en el original) En el día de hoy lo que ha executado es tomar un colchón de la cama, saliéndose de las salas donde la mía habita y haberse ido a las de una vecina, para estar en su plena libertad y sin sujeción alguna... manifestando que no quiere hacer vida maridable... por todo lo cual, siendo lo expuesto y principalmente la pernoctación a deshoras, contra la voluntad de su marido, causa de divorcio, a Vuestra señoría pido y suplico... se sirva declarar el divorcio... y que la mi parte no está obligado a hacer vida maridable con la susodicha... y la dicha mi parte es pobre de solemnidad ${ }^{46}$.

Conocidos en el barrio desde la infancia (no parece que hubieran salido de él hasta la fecha), los amigos "más selectos" procedían del sector servicios. Ubicados sus negocios en las callejas del barrio, cortadores de carne, canasteros, moledores de chocolate, zapateros, albañiles, barqueros o vendedores de aguardiente dibujaban un panorama de hombres de profesión humilde y de atención pública, llamados a deponer de la vida de ambos y, básicamente de los desmanes de Francisca; recordaban peleas, a veces con armas blancas ("en una ocasión a presencia del testigo tomó la susodicha una espada para darle con ella, estando en su propio cuarto, y ultrajándolo de palabras, que el testigo los medió" 47 ), insultos ("que era un alma de tal y se ensuciaba en ella"48) y otras acciones vejatorias.

La demanda mencionaba acciones previas de la Justicia Real contra la mujer y sus consecuentes amonestaciones para la reanudación de la vida maridable; pero no especificaba las razones específicas del proceso. ¿A qué causa se refería el esposo y por qué ocultaba la acusación básica? Unos meses atrás, en el mismo año de 1780, Francisca había iniciado una relación ilícita con un tal Francisco Moreno, cortador de carne y provisor de cuanto la mujer consideraba necesario. Desconociéndolo el marido, la amistad continuaría durante unos meses hasta ser descubiertos, ignoramos la forma o los caminos de la delación, y procediendo entonces la querella particular del

\footnotetext{
46 Ibídem. Demanda de divorcio.

47 Testimonio de Juan González, cortador de carne. El Salvador.

48 Testimonio de Juan de Alanís, moledor de chocolate. El Salvador.
} 
cónyuge ante la Justicia Real. Como consecuencia, ambos "cómplices" serían presos $\mathrm{y}$, posteriormente, reconvenidos: ella, a volver con el marido, él, bajo apercibimiento de ocho años de prisión, a no rondar ni tratar a la dicha Francisca. Obviamente ambas demandas se cruzaron: la de adulterio originaría con posterioridad la propia de divorcio, propiciando la fuga de la esposa y la continuidad de su relación con Moreno, unos meses más. Pero -fijémonos- ante la Justicia eclesiástica el esposo no mencionará -no parece que deseara mencionarlo- tal infidelidad probada y reconocida por la propia cónyuge, como si no hiciera falta lastimar -aún más- su honra. La de él.

Un matrimonio de condición muy humilde: él trabajaba cuando podía en cortar pescado, ella vendía mistela, "tajadillas" y aguardiente. Mal avenidos, callejeros ambos, con infidelidades -ella recordará alguna de Josef- por ambas partes. ¿De qué edades? El proceso de adulterio contra Francisca nos la presenta de 24 años en 1780 $\mathrm{y}$, al parecer, mantenida por su amante quien, por aquellos días, representaba para la mujer cierta seguridad ante las penurias del esposo. Siendo cortador de carne, el amigo le pagaba la casa en donde se refugia Francisca en sus huidas, ascendiendo a "la peseta y tres cuartos de carne diarias", (además del alquiler ya citado), el alcance de sus mantenimientos. Lo mejor: ambos reconocerán trato y amores. Ella, alegando edad e ignorancia, apunta su culpa durante su matrimonio y más tarde en los tiempos de distanciamiento de su esposo; él aceptando los tratos y el coste, pero sin asumir ser la causa de la separación de la pareja. De este porte:

Ella:

Dijo que es cierto y que, como muchacha sin entendimiento y con poca experiencia, ha tratado ilícitamente con el referido Francisco Moreno, durante el tiempo que estuvo con su marido, sin entenderlo éste, y, separada de él, ha continuado más francamente, y éste le daba lo que hacía falta por su vestir ${ }^{49}$.

Él:

Que ha estado nueve meses comunicando a Francisca Santana, suministrándole la peseta y tres cuartos de carne diarias, y pagándole la casa, sin que se entienda que la separación de su marido había sido por su causa ${ }^{50}$.

El reconocimiento les había valido sentencia condenatoria, pero, en compensación, la suavidad del castigo eludía prisiones y carcelerías. Según citábamos, Francisco sería apercibido bajo pena de ocho años de presidio. Francisca, condenada conjuntamente en las costas, sería soltada "con consejos cristianos" a fin de favorecer su vuelta, haciendo así "vida maridable con su marido" ${ }^{1}$.

El cruzamiento de procesos -causa criminal de adulterio primero, pleito de divorcio después- aportaba al expediente un número bastante de testigos; a ellos, en tema tan importante como el de separación de cuerpos, se añadiría la petición de informes a los curas de la parroquia de donde Francisca era feligresa. El Salvador contaba con tres beneficiados curados; los tres enviarían "resultas" al tribunal eclesiástico. Y, según testimonios de los vecinos y del alcalde del barrio, escribirían que "es una mujer

\footnotetext{
49 Ibídem. Confesión de la rea en el proceso por adulterio contenido en la causa.

50 Ibídem. Confesión de Francisco Moreno en el proceso por adulterio de F.S.

51 Ibídem. Sentencia contra ambos en el proceso citado. Dictada en 3-XII-1780.
} 
que da y ha dado mucho escándalo en dicha calle, así con sus malas palabras como con sus obras aunque en el día dicen que se ha mudado de dicha calle". Las fuentes de información -vecinos, autoridades- ratifican los mismos orígenes. Los sacerdotes, en collación populosa como la céntrica de El Salvador, no parecían conocer de cerca las actuaciones de Francisca. A fines del XVIII, el contacto cercano con el pueblo se distanciaba.

"En el día dicen que se ha mudado de dicha calle". El informe de los curas coincidía con la fuga de Francisca, conocedora de los autos de divorcio. Es entonces cuando, primero, cambiará de barrio, segundo huirá a Cádiz, Isla de León, en donde -confesará más tarde- vivirá en compañía de una hermana casada. Pero Francisca y Josef volvieron. El testimonio de la esposa ratifica una paralización del pleito de divorcio por aquellos días (finales de 1780); según parece, habían reanudado su relación conyugal, intermitentemente, habiendo en ocasiones "cohabitado y dormido juntos". En el ínterim, infidelidades varias, acusaciones mutuas: él, que ella había contraído el mal gálico, ella, que era enfermedad del tabardillo; él, que andaba por las tabernas, ella, que lo hacía por ser vendedora de aguardiente "para mantenerse"...y vecinas que veían peligrar sus matrimonios por la presencia de Francisca en ciertas meriendas y convidadas, al calor de las risas y los festejos en donde se hallaban los maridos. Una visión -la de la mujer "Eva" tentadora de hombres- que reproduce las desestimaciones de entonces: a la manera del mejor Tertuliano, Francisca se convertía, en la crítica de sus vecinas en "puerta del diablo", engatusadora de hombres ${ }^{52}$.

Quince años después, las desavenencias y los conflictos continuaban; el matrimonio de Josef y Francisca se alimentaba de broncas y enfrentamientos públicos que, de nuevo entre querellas particulares -ahora de la esposa contra el marido por relación ilícita-, reabrirían la demanda de divorcio. En efecto, en 1795, en 14 de septiembre, se le notificará a la mujer (a la sazón en Cádiz) dicha solicitud. ¿Por qué ahora? De nuevo un cruce de demandas: la relación del marido con una tal María Plaza había originado la acusación de la esposa "por la separación, mal trato y abandono de que su marido le ha tenido por la amistad torpe e ilícita con María Plaza", de estado soltera, relación por la cual se encontraba preso en la cárcel real el dicho Josef. Observemos: a fines del XVIII, las querellas de adulterio parecían optar por la Justicia Real, siendo como sabemos tal delito de fuero mixto. Ambas justicias entendían de los tratos extraconyugales y ambas justicias cooperaron (pero retrasaron los autos) en poner "orden" en las relaciones maritales del matrimonio. Para Francisca, la demanda de divorcio de su marido -tras quince años dormida- tenía su origen en la causa criminal iniciada por ella en razón de la amistad mencionada -"por la antigua amistad no lícita que ha muchos años tiene con una mujer soltera"- razón por la cual -justificabahabía vuelto a Cádiz, refugiándose de nuevo en casa de la hermana. Y las acusaciones reviven una historia plena de resentimientos. Desde la cárcel el marido recordará su relación antigua con el cortador de carne -Francisco Moreno- con diferencias: que si

\footnotetext{
52 Resumen del espionaje realizado por el marido a la esposa: "y vio como entraba con varios hombres que se introdujeron en la pastelería de la calle Cerrajería, donde se estuvieron convidando y bebiendo en demasía, tanto que, noticiosa la mujer del dicho barquero, vino a las casas de la dicha vecina, diciendo eran unas pícaras tales y tenían mal entretenido a su marido como también que éste se había quedado en dichas salas a dormir con ellas... dando el mayor deshonor a mi parte". Testimonio del marido.
} 
los amantes habían reconocido nueve meses, el marido elevaba el "trato" a tiempo de cuatro años, agravando los cargos hasta el de puta ramera, para lo que usaría de las declaraciones de hasta catorce testigos de diversa índole e idéntica extracción, cómplices en su pecado: marineros, albañiles, barberos... desfilarían por la justicia añadiendo delito a delito.

En 7 de octubre de 1796, el tribunal eclesiástico dictará sentencia de divorcio ${ }^{53}$, condenando a Francisca en las costas y recluyéndola en la Casa de las Recogidas, calle del Rosario, desde donde apelará, primero para ser mantenida (pasándole él los alimentos), segundo, y por la misma razón, para recurrir el dictamen de divorcio.

No quedaría así. En 25 de noviembre de un año después, y en segunda instancia, el nuncio revocaría la sentencia, reconociendo la obligatoriedad de la vida maridable "con la paz y quietud y buena correspondencia que es debida". Las apelaciones del esposo serían rechazadas, finalizando autos eclesiásticos y pleitos matrimoniales en recurso de fuerza que Josef planteará a fines de siglo: 16 de enero de 1799.

Nada sabemos desde entonces.

La vida conyugal de Francisca y Josef recorre bien la historia de un divorcio en los márgenes de la sociedad, de un matrimonio contraído -posiblemente- sin presiones ni condicionantes diferentes a las voluntades (nacieran de la necesidad o del afecto) y que, en sus primeros años debió ser relativamente feliz. Entre las pertenencias inventariadas de la esposa, al hilo de las diferentes causas, un recuerdo sentimental del marido: dos navajas plateadas con una inscripción: "¡Viva nuestro amor!" 54 . Es evidente que las formas materiales de la sensibilidad y de su expresión tienen plasmaciones tan diversas como la propia personalidad.

\section{CONCLUSIONES}

Los conflictos conyugales conocidos que generaron abandono, ruptura o disolución del vínculo muestran en la archidiócesis hispalense, a lo largo del XVIII, una vitalidad conforme a la media. Sin llegar a la experimentada en la diócesis gaditana, pese a su extensión, los expedientes contabilizados en los Libros de Índices ratificaban la primacía de los divorcios y abandonos por encima de los pleitos de nulidad eclesiástica, y confirmaban, en su segunda mitad, el proceso de sustitución de los abandonos espontáneos (con sus consecuentes denuncias, bien del cónyuge dejado, bien por vía de oficio) por soluciones que buscaban la legalidad por el camino del divorcio. Considerando la obligatoriedad eclesiástica -y civil- de la vida maridable, cualquier distanciamiento conocido -lo que no era difícil en los barrios ni en las casas patioaportaba un número de testigos suficiente para declarar en los pleitos ante las diferentes Justicias: la real y la ordinaria del arzobispo.

\footnotetext{
53 "Se declara el divorcio pretendido por Josef González quo ad torum et mutuam cohabitationem y en su consecuencia, que no está obligado a hacer vida maridable con Francisca Santana, su mujer, a quien se le condena en las costas".

54 Inventario de las pertenencias que se encontraron a Francisca Santana. Causa criminal por adulterio contenida en el pleito de divorcio. Sevilla, 1780. AGAS, Sección Justicia, Serie Criminales, leg. 1049.
} 
Confirmando el perfil de los demandantes europeos y americanos, las mujeres primaban en los casos de divorcio, y los causales alegados demostraban que la violencia doméstica se hallaba detrás de la mayoría de los procesos. En la archidiócesis andaluza, el riesgo de vida argumentaba los discursos de las esposas que buscaban en la separación eclesiástica un camino, no tanto de estabilidad, cuanto de supervivencia. A veces precedido de abandono del hogar, lo que les permitía continuar pleito y asegurar vida. La rebeldía de las mujeres que demandaron venía marcada, casi siempre, por discursos de desesperación que recordaban, con actitudes diferentes, palizas, persecuciones, vejaciones o insultos.

Pero no necesariamente los cuadros de las mujeres demandantes presentaban los mismos tonos. Las que quedaron en la metrópoli, efecto de la Carrera de Indias, requerían asistencia y mantenimientos; podían, o no, acusar a sus maridos de doble vida según los rumores que les llegaban de América, pero no por ello añoraban ni tiempos pasados ni convivencias antiguas; a veces el Océano y las distancias alargaban ficticiamente la "salud" matrimonial, iniciándose los pleitos al ritmo del comienzo de la convivencia: que no todos los maridos procedentes de Indias contaron con acogidas festivas.

El adulterio, la insumisión y la pérdida de honor y honra configuraron los causales de los hombres en sus demandas de separación. Y, según descubrimos, entre las denominadas demandas "cruzadas" debieron ser más las relaciones ilícitas que se ocultaron bajo otras causas, que las reconocidas en los pleitos. Huyendo del desprestigio que suponía -sobre todo para el varón- la asunción de las infidelidades de la esposa, como las sospechas de consentimiento, intuimos que tras las quejas de insumisión, desobediencia o abandono, se encontraban, también, situaciones ciertas de relaciones ilícitas; ilícitas y, por tanto, adúlteras.

El panorama divorcista del arzobispado de Sevilla prima a los grupos medios. Entre los expedientes conservados, las profesiones de cierta solvencia, los negocios familiares, los criados y la reivindicación de las dotes supuestamente gastadas reproducen un cuadro algo distante de los obtenidos en otros estudios peninsulares. Aquí los grupos populares (más abundantes en los casos de abandono por vía de oficio) son numéricamente inferiores. Creemos que los pleitos de separación protagonizados por los sectores humildes vendrían precedidos de otro tipo de sumarias nacidas en conflictos conocidos de adulterio y malos tratos; conflictos causantes de demandas de divorcio sólo en casos extremos. Así, a diferencia de los planteamientos de los grupos superiores, la infidelidad o la violencia doméstica en los hogares populares por ser conocidas, judicialmente, incrementarían proporcionalmente los procesos criminales por cuestiones de conducta, en mayor medida que los de divorcio. Y los pleitos matrimoniales aparecerán cosidos a los de expedientes iniciados por otras conductas encausadas, formando parte de fondos documentales diferentes. Ello elevaría, si bien moderadamente, las cifras obtenidas en la segunda mitad del siglo relativas a los procesos populares.

Por las mismas causas, la percepción de la infidelidad manifiesta, claramente, estimaciones diferentes según género. Al margen de la sensibilidad particular del problema, que creemos superior a la recogida en el discurso, es obvio que los hombres demostraban una intolerancia superior a las relaciones de sus mujeres; y que ellas, 
aun declarando las de sus maridos, no consideraban -en términos de causalidad- tales actitudes lo suficientemente relevantes como para protagonizar demandas; en tanto que el abandono -y sus consecuencias materiales- contaba con el rechazo general. A fin de cuentas sabían (ellas y sus defensas) que, si bien la fidelidad y la asistencia constituían la esencia de los deberes conyugales del esposo, su observancia flaqueaba; al otorgar una importancia superior al mantenimiento de la mujer, familia y hogar, aceptaban diferentes roles y distintas responsabilidades, y parecían conformarse -ante la justicia- con cierta continuidad en el sostén económico y material.

El concepto de abandono, además, lo suponemos relativo. La marcha de maridos a la Armada, a Indias o hacia el centro de los negocios, por entonces Cádiz y sus alrededores, convertía en separaciones de hecho lo que de derecho aún seguía siendo interrupción por circunstancias de la vida maridable. Por conservar su honor y por no ser tachadas de mujeres solas o desamparadas, con lo que ello comportaba, muchas mujeres, prácticamente abandonadas, se confesaban, en buena ley, casadas y bien casadas. Como María Casares, vecina de Triana, quien se definía "mujer casada con marido ausente en Indias tiempo de seis años", defensora a ultranza de la existencia de marido y estatus, ante las preguntas de un fiscal dudoso de tal condición:

niega haberse fingido casada pues realmente lo es, según tiene entendido por carecer de noticia de que haya muerto dicho su marido, porque, aunque en su ausencia no le ha escrito más que una carta, ha tenido noticia la confesante, hará dos años y medio, de que vive y aun le espera la confesante ${ }^{55}$.

El retrato del divorcio en los sectores populares -que hemos traído a colación en una historia de caso- refleja la realidad de las relaciones conflictivas en una sociedad abierta a las migraciones locales, usadas aquí como recurso para marcar distancia familiar y sentimental. Durante quince años, las vidas de Francisca y Josef volcaron en expedientes judiciales los problemas de su convivencia. Sus profesiones les convertían en personajes de la calle, de gentes de condición humilde. Enfrentados desde casi el comienzo de su vida conyugal, las infidelidades mutuas y los maltratos de palabra y obra (aquí en una doble dirección) no ocultan (documentalmente hablando) un tiempo de relaciones más o menos felices. Aquel ¡Viva nuestro amor! grabado entre las pertenencias conservadas de la esposa refiere, como poco, algunos días alegres de estabilidad, pero no ocultan las estimaciones, los valores y los discursos de entonces. Bastantes años después, a fines del XIX, en los Episodios Nacionales, Pérez Galdós pondrá en boca de su personaje Marcial, "el Medio-hombre", una confesión con pretendidos tintes cómicos, que seguía manteniendo el concepto de la esposa como mujer "propia": "de los palos que le daba a mi mujer hace treinta años, me arrepiento, aunque creo que bien dados estuvieron porque era más mala que las churras y con un genio más picón que un alacrán " ${ }^{6}$. En el trasfondo de la violencia, causal básico en las separaciones protagonizadas por mujeres, se hallaba (y continuaría hallándose) el papel corrector del esposo para con la esposa.

\footnotetext{
55 Candau, 2007.

56 PÉrez Galdós, 1881, p. 141.
} 


\section{REFERENCIAS BIBLIOGRÁFICAS}

CAmpo Guinea, María del Juncal

1998 Comportamientos matrimoniales en Navarra (siglos XVI-XVII). Pamplona. Gobierno de Navarra.

CANDau Chacón, María Luisa

2002 "Un mundo perseguido: delito sexual y justicia eclesiástica en la España moderna". En Fortea Pérez - Gelabert González - Mantecón Movellán (coords.), Furor et rabies. Violencia, conflicto y marginación en la Edad Moderna. Santander. Universidad de Cantabria, pp. 403-432.

2007 "Disciplinamiento católico e identidad de género". Manuscrits. Barcelona, no 25, pp. 211-237.

2009 "Una historia de tres en Ayamonte: el caso del tabernero prófugo y las dos Josephas". En Vv.AA., Sucesos curiosos en la Andalucía del Antiguo Régimen. Sevilla. Junta de Andalucía, pp. 151-179.

Ciappelli, Giovanni

2006 "I processi matrimoniali: quadro di raccordodeirisultatidellaschedatura (Venecia, Verona, Napoli, Feltre e Trento, 1420-1803”. En SeIDEL Menchi - Quaglioni (eds.), I tribunali del matrimonio (secoli $X V$-XVIII). Bolonia. Societá Editrice il Mulino, pp. 67-100.

Cliche, Marie Aimée

1995 "Les procès en séparation du corps dans la région de Montréal, 1795-1879". Revue d'histoire de l'Amérique française. Montréal, vol. 49, n 1. En http://id.erudit.org/ iderudit/305398ar

Costa, Marie

2009 "Divorciarse en Cataluña a finales del Antiguo Régimen: ¿rechazo o solidaridad social?" En Gonzalbo Aizpuru (coord.) - Molina Gómez (comp.), Familias y relaciones diferenciales: género y edad. Murcia. Universidad de Murcia, pp. 95-108.

DÁvila Mendoza, Dora

2005 Hasta que la muerte nos separe. El divorcio eclesiástico en el arzobispado de México, 1702-1800. México. El Colegio de México.

De la Pascua Sánchez, María José

2012a "Conflictividad, criminalidad y violencia en la época Moderna: aproximación histórica desde la perspectiva integradora de la vida cotidiana”. En PEÑA DíAz (ed.), La vida cotidiana en el mundo hispánico: (siglos XVI-XVIII). Madrid. Abada Editores, pp. 159-176.

2012b "Violencia y familia en la España Moderna". En CASTELlano - LóPEZ-GuADALuPE (eds.), Actas de la XI Reunión científica de la Fundación Española de Historia Moderna. Ponencias y conferencias invitadas. Granada. Universidad de Granada, pp. 127-157.

EIRAS Roel, A.

2009 "Ciudades, villas y pueblos: estructura de la población y criterios de estratificación urbana”. En Bravo Caro - Sanz SAmpelayo (eds.), Población y grupos sociales en el Antiguo Régimen. Actas de la IX Reunión Cientifica de la FEHM. Málaga. Universidad de Málaga, pp. 33-130. 
Fauve-Chamoux, Antoinette

2002 "El matrimonio, la viudedad y el divorcio". En KerTZER - BARBAGLi (comps.), La vida familiar a principios de la era moderna (1500-1789). Historia de la familia europea. Barcelona. Paidós, pp. 331-376.

Gálvez Ruiz, M. Ángeles

2007 "Violencia patriarcal en el México Colonial”. En MuÑoz MuÑoz - Gregorio GIL - SÁnchez Espinosa (coords.), Cuerpos de mujeres: miradas, representaciones e identidades. Granada. Universidad de Granada, pp. 309-328.

Gil Ambrona, Antonio

1992 “Las mujeres bajo la jurisdicción eclesiástica: pleitos matrimoniales en la Barcelona de los siglos XVI y XVII". En BIRRIEL SALCEDo (coord.), Nuevas preguntas, nuevas miradas: fuentes y documentación para la historia de las mujeres (siglos XIII-XVIII). Granada. Universidad de Granada, pp. 113-138.

2008 Historia de la violencia contra las mujeres. Misoginia y conflicto matrimonial en España. Madrid. Cátedra.

GHIRARDi, Mónica - Irigoyen LóPez, Antonio

2009 “El matrimonio, el Concilio de Trento e Hispanoamérica”. Revista de Indias. Madrid, vol. LXIX, nº 246, pp. 241-272.

GonzÁLEz Gómez, Yéssica

2011 Conflicto, violencia sexual y formas de transgresión moral en el obispado de Concepción, 1750-1890. Huelva. Universidad de Huelva. Tesis doctoral inédita.

Hernández GonzÁLEz, Manuel

1998 "La familia canaria en el Antiguo Régimen”. Tebeto. Puerto del Rosario, nº 1, pp. 30-50.

Hernández Franco, Juan - Meriñán Soriano, Enrique

1997 "Notas sobre sexualidad no permitida y honor en Lorca (1575-1615)". En LóPEZ Cordón - CARbonell Esteller (eds.), Historia de la mujer e historia del matrimonio. Murcia. Universidad de Murcia, pp. 131-138.

LAVALLÉ, Bernard

1999 Amor y opresión en los Andes coloniales. Lima. IEP Ediciones.

LoREnZo PINAR, Francisco Javier

1999 Amores inciertos, amores frustrados (conflictividad y transgresiones matrimoniales en Zamora en el siglo XVII). Zamora. Semuret.

MacíAs DomíngueZ, Alonso Manuel

2012 "Conflictividad matrimonial en el arzobispado de Sevilla durante la Edad Moderna (siglo XVIII)". En Jiménez Estrella - Lozano Navarro (eds.), Actas de la XI reunión cientifica de la FEHM. Conflictividad y violencia en la Edad Moderna. Granada. Universidad de Granada, t. 2, pp. 474-486.

2014 El matrimonio, espacio de conflictos. Incumplimiento de promesa, divorcio y nulidad en la Archidiócesis Hispalense durante el siglo XVIII. Huelva. Universidad de Huelva. Tesis doctoral inédita.

2015 "La conflictividad matrimonial bajo control. La intermediación de la comunidad como agente de resolución de conflictos entre casados (Sevilla, siglo XVIII)". En Iglesias Rodríguez - Pérez García - Fernández Chaves (eds.), Comercio y cultura en la Edad Moderna. Sevilla. Universidad de Sevilla, pp. 1751-1765. 
Mantecón Movellán, Tomás Antonio

1997 Conflictividad y disciplinamiento social en la Cantabria rural del Antiguo Régimen. Santander. Universidad de Cantabria - Fundación Marcelino Botín.

2002 "La violencia marital en la Corona de Castilla durante la Edad Moderna". En IRIGOYEN LóPEZ - PÉREZ ORTIZ (eds.), Familia, transmisión y perpetuación (siglos XVI$X I X)$. Murcia. Universidad de Murcia, pp. 19-55.

Mira CABAllos, Esteban

1993 La población en Carmona en la segunda mitad del siglo XVIII. Carmona. Ayuntamiento de Carmona.

Morgado García, Arturo

1994-1995 “El divorcio en el Cádiz del siglo XVIII”. Trocadero. Revista del Departamento de Historia Moderna y Contemporánea. Cádiz, nº 6-7, pp. 125-138.

MuchemBLED, Robert

2010 Una historia de la violencia. Del final de la Edad Media a la actualidad. Madrid. Paidós, pp. 245-248.

PÉREZ GALDós, Benito

1881 Episodios nacionales. Trafalgar. Madrid. Ed. Facsímil.

PÉREZ MuÑoz, Isabel

1992 Pecar, delinquir y castigar: el tribunal eclesiástico de Coria en los siglos XVI y XVII. Cáceres. Institución cultural "El Brocense" - Diputación de Cáceres.

Pineda Alfonso, José Antonio

2015 El gobierno arzobispal de Sevilla en la Edad Moderna. Sevilla. Universidad de Sevi1la. Tesis doctoral inédita.

Po-Chia Hsia, Ronnie

2010 El mundo de la renovación católica, 1540-1770. Madrid. Akal.

Ruiz Torres, Pedro

2008 Reformismo e Ilustración. Barcelona. Crítica.

Ruiz SAStre, Marta

2011 Matrimonio, moral sexual y justicia eclesiástica en Andalucía occidental: la Tierra Llana de Huelva (1700-1750). Sevilla. Universidad de Sevilla.

SÁNCHEZ CID, Francisco Javier

2011 La violencia contra la mujer en la Sevilla del Siglo de Oro (1569-1626). Sevilla. Universidad de Sevilla.

SeIDEL Menchi, Silvana

2005 "La svolta di Trento. Richerche italiana sui processi matrimoniali". En UsunÁRIZ Garayoa - Arellano Ayuso (eds.), El matrimonio en Europa y el mundo hispánico: siglos XVI y XVII. Madrid. Visor Libros, pp. 145-166.

TESTÓN NúÑEZ, Isabel

1985 Amor, sexo y matrimonio en Extremadura. Badajoz. Universitas Editorial.

Torremocha Hernández, Margarita

2015 "Modelos de espiritualidad barroca. 'De la que tomó estado matrimonial"'. En BurriEZA SÁnchez (ed), El alma de las mujeres. Ámbitos de espiritualidad femenina en la modernidad (siglos XVI-XVIII). Valladolid. Universidad de Valladolid, pp. 181-211.

Villalba PÉrez, Enrique

2004 ¿Pecadoras o delincuentes?: delito y género en la Corte (1580-1630). Madrid. Calambur. 